Proc. Indian Acad, Sci. (Anim. Sci.), Vol. 91, Number 6, November 1982, pp. 539-552.

(C) Printed in India.

\title{
Observations on the natural history and population ecology of the social wasp Ropalidia marginata (Lep.) from Peninsular India (Hymenoptera: Vespidae)
}

\author{
RAGHAVENDRA GADAGKAR, MADHAV GADGIL, \\ N V JOSHI and A S MAHABAL* \\ Centre for Theoretical Studies, Indian Institute of Science, Bangalore 560012 , India \\ * Zoological Survey of India, Pune 411005 , India
}

MS received 23 June 1982

\begin{abstract}
Ropalidia marginata, the most common Indian social wasp, belongs to a crucial stage of social evolution showing no abvious morphological caste differentia tion but a behavioural caste differentiation and a dominance hierarchy that appears to influence division of labour. The nests consist of a single open comb that can sometimes have up to 500 cells and 10 pedicels. Nests are initiated and abandoned all round the year. Initiation is by 1-20 foundresses, 1-4 being the most common number. There is a great deal of variation in brood developmental times both within and between nests. Male progeny disappear from the nest soon after emergence while daughters stay on at the parent nest for a mean period of about a month. Small nests have a single egg layer while large nests have two or more females with well developed ovaries that presumably lay eggs. Mast nests are short-lived, small nests being highly susceptible to failure. Large nests are less susceptible to failure but the emergence of multiple egg layers reduces the average relatedness of workers to the brood which presumably is the cause for large scale emigrations from these nests. An interaction of ecological and soical factors therefore appears to determine the grawth of a nest.
\end{abstract}

Keywords. Sacial wasp ; Ropalidia marginata ; natural history ; population ecology; hymenoptera ; caste differentiation.

\section{Introduction}

Recent years have witnessed a great surge of interest in social hymenoptera because the emergence of a considerable body of theoretical ideas (Hamilton $1964 \mathrm{a}, \mathrm{b}$; Lin and Michener 1972; Alexander 1974) have raised hopes that herein lies the key to understanding the evolution of social behaviour (West-Eberhard 1969, 1975 ; Wilson 1971, 1975 ; Jeanne 1972, 1980 ; Michener 1974 ; Trivers and Hare 1976 ; Litte 1977, 1979, 1981 ; Starr 1979). Bees and wasps are of special interest in this connection because they exemplify a series of stages in the evolution of 
sociality from the completely solitary to the highly advanced eusocial species (see Evans and West-Eberhard 1970 ; Michener 1974 ; Wilson 1971).

Ropalidia marginata is the commonest social wasp of Peninsular India (Van der Vecht 1962). This species shows cooperative brood care, reproductive caste differentiation and overlap of generations (Gadgil and Mahabal 1974 ; Gadagkar 1980 ; Gadagkar and Joshi 1982b, 1983a ; Gadagkar unpublished observations) and hence can be called eusocial according to the classification of Michener (1969). There is no obvious morphological differentiation between egg layers and non egg layers (Gadgil and Mahabal 1974) and division of labour is brought about by a dominance hierarchy among the females belonging to a nest (Gadagkar 1980). Analysis of the time-activity budgets of adults on $R$. marginata nests has in fact revealed the presence of a behavioural caste differentiation in this primitively eusocial wasp (Gadagkar and Joshi 1982b, 1983a).

Apart from these few recent studies there is very little information in the literature about this interesting genus (Roubaud 1916 ; Carl 1934 ; Darchen 1976 ; Belvadi and Govindan 1981 ; Gadagkar and Joshi 1982a,c, 1983b). Moreover, in addition to understanding reproductive differentiation and social organization, information on the dynamics of initiation, growth and extinction of colonies is essential before we even begin to speculate about the factors that might be responsible for the origin and maintenance of sociality. We present in this paper the results of our observations on the natural history as well as population ecology of Ropalidia marginata in Peninsular India.

\section{Materials and methods}

\subsection{Study sites}

In all we have observed 125 nests of Ropalidia marginata from the cities of Pune $\left(18^{\circ} 30^{\prime} \mathrm{N}\right.$ and $\left.73^{\circ} 53^{\prime} \mathrm{E}\right)$ (45 nests) and Bangalore $\left(13^{\circ} 00^{\prime} \mathrm{N}\right.$ and $\left.77^{\circ} 32^{\prime} \mathrm{E}\right)$ (80 nests) at various times over a period of nine years from October 1971 to October 1980.

\subsection{Population fluctuations}

Our population observations include records of the numbers of pupae and adults in a nest maintained at roughly 8-10 day intervals. Such observations were maintained on three nests in Pune from October 1971 to May 1973 and for 35 nests in Bangalore from October 1974 to October 1976. The 35 nests in Bangalore were all located on the windows of one building about 20,000 sq.ft. in area and a height of about $40 \mathrm{ft}$. Our records of the population in this site also provide information on (i) seasonal variations in numbers of adult wasps, pupae and nests, (ii) seasonality of initiation and abandoning of nests and (iii) life spans of nests.

\subsection{Brood developmental times}

For one nest in Pune and two nests in Bangalore the contents of each cell in the nest were noted to provide estimates of developmental times of the eggs, larvae and pupae. 


\subsection{Period of residence of adults on nests}

Every adult on two nests in Bangalore was marked with a unique spot of quick drying paint immediately upon emergence without removing it from the nest. A census of all the adults present on the nests was taken on alternate days from November 1979 to June 1980 to provide records of the total period of residence of 60 females and 3 males.

\subsection{Collection of nests}

28 nests in Pune and 31 nests in Bangalore were collected taking precaution not to bias the sampling in favour of any particular size class of nests and to collect entire combs along with all the adults and immature stages. The numbers of pedicels, cells, eggs, larvae, pupae and adults were determined. The adults were sexed and the females were dissected to determine the state of development of their ovaries. The females were classified arbitrarily into 3 catagories : those with undeveloped ovaries, those with moderately developed ovarios and those with well developed ovaries on the basis of maximum ovariole width. Those classified as 'with well-developed ovaries' appeared to have mature eggs and were probably laying eggs. These females are designated as egg layers. We do not however know if all females with well-developed ovaries actually laid eggs.

\section{Results}

\subsection{The nest and its structure}

R. marginata builds nests with simple, open (Gymnodomous according to the classification of de Saussure (1853-59) and Richards and Richards (1951)) combs the construction of which begins with the laying down of the pedicel which is usually $5-10 \mathrm{~mm}$ long and about $1 \mathrm{~mm}$ thick. The first cell is constructed at the tip of this pedicel and the subsequent cells are added either all round the first cell or only on one side so that in larger combs the initial pedicel may either end up being approximately in the centre of a layer of cells or at one extreme end. As the comb grows in size the initial pedicel is enlarged in width and may grow up to about 5-6 mm in diameter in large combs. In addition to enlarging the original pedicel, new thin pedicels (about $1 \mathrm{~mm}$ in diameter) that reinforce the attachment of the comb to the substratum are added at several points. Most small combs ( $<100$ cells) have a single pedicel while large combs $(>100$ cells) often have more than one pedicel (table 1). The largest comb we have recorded had about 500 cells and 10 pedicels, the latter also being the largest number of pedicels recorded on a comb.

All but one of the nests recorded, has a single comb per nest. In one case however, there were two combs within about $20 \mathrm{~mm}$ of each other and the adults clearly moved between these two combs.

\subsection{Initiation of nests}

Nests of $R$. marginata are initiated and abandoned all round the year (table 2). New nests are initiated by 1-20 females, 1-9 being the commonest number (figure 1). 
Table 1. Nests with different number of pedicels

\begin{tabular}{ccccccc}
\hline & \multicolumn{6}{c}{ Frequency of nests with different } \\
$\begin{array}{c}\text { Number of } \\
\text { cells in } \\
\text { nest }\end{array}$ & $\begin{array}{c}1 \\
\text { Pedicel }\end{array}$ & $\begin{array}{c}2 \\
\text { Pedicels }\end{array}$ & $\begin{array}{c}3 \\
\text { Pedicels }\end{array}$ & $\begin{array}{c}4 \\
\text { Pedicels }\end{array}$ & $\begin{array}{c}7 \\
\text { Pedicels }\end{array}$ & $\begin{array}{c}10 \\
\text { Pedicels }\end{array}$ \\
\hline $1-100$ & 17 & 3 & $\ldots$ & $\ldots$ & $\ldots$ & $\ldots$ \\
$101-200$ & 1 & $\ldots$ & 2 & $\ldots$ & $\ldots$ & $\ldots$ \\
$201-300$ & $\ldots$ & $\ldots$ & $\ldots$ & $\ldots$ & $\ldots$ & $\ldots$ \\
$301-400$ & 1 & 1 & $\ldots$ & 1 & $\ldots$ & $\ldots$ \\
$401-500$ & $\ldots$ & 1 & 2 & $\ldots$ & 1 & 1 \\
\hline
\end{tabular}

Table 2. Year-round initiation and abandoning of nests*

\begin{tabular}{lcc}
\hline Month & $\begin{array}{c}\text { Number } \\
\text { of nests } \\
\text { initiated }\end{array}$ & $\begin{array}{c}\text { Number } \\
\text { of nests } \\
\text { abandoned }\end{array}$ \\
\hline
\end{tabular}

\begin{tabular}{lll}
\hline January & 4 & 3 \\
February & 0 & 3 \\
March & 0 & 1 \\
April & 3 & 2 \\
May & 5 & 2 \\
June & 1 & 8 \\
July & 1 & 2 \\
August & 8 & 7 \\
September & 3 & 1 \\
October & 2 & 1 \\
November & 4 & 2 \\
Decsmb:r & 0 & 0 \\
\hline
\end{tabular}

Data pooled from observations throughout the study period both in Bangalore and Pune.

In many cases the initial single foundress appears to be joined by other females within a few days of iaitiation of the nest. When newly emerging females were marked with spots of paint, it was noticed that some of the newly emerged individuals were not spending every night on the parent nest but were occasionally missing for 2-3 days before returning to it. It is possible that these individuals had been visiting other newly founded nests on the nights they were absent. There were emigrations of large number of adults from nests which had grown to more than 40-50 adults in size. Groups of individuals from these exoduses probably constitute the initial set of foundresses for many nests, 


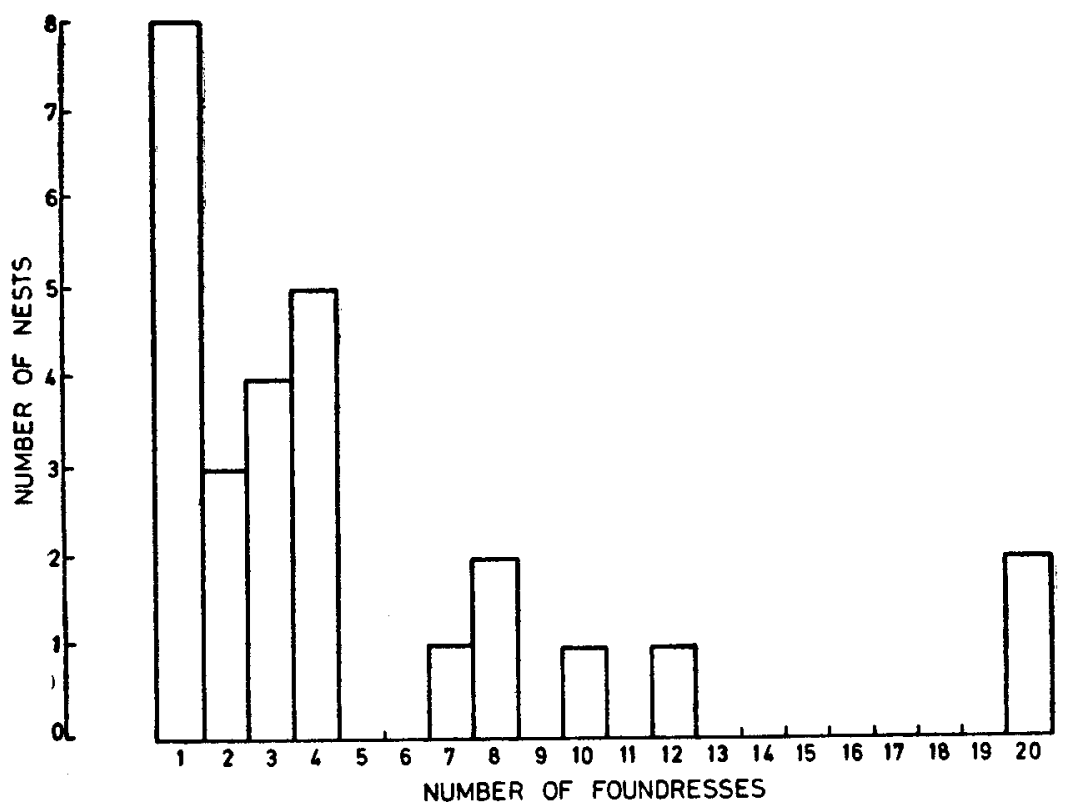

Figure 1. Frequency distribution of the number of nests with different numbers of foundresses.

\subsection{Brood developmental times}

The accurate determination of brood developmental times is beset with a number of problems and the estimates given here are only to be treated as first approximations. The duration of the egg, larval and pupal stages both in Pune and Bangalore are given in table 3. In each stage the duration in Pune is much less than in Bangalore. This difference could either be a genuine idifference due to different environmental conditions in Pune and Bangalore. However, it cannot be ruled out that the differences are simply a result of small sample sizes in terms of the number of nests studied. The data in Pune in fact represent a single nest and that in Bangalore two nests. The difference could therefore be simply a manifestation of different stages in the nest cycle or of different local conditions. The nest in Pune, may have been located close to a good food source and therefore the difference may not even reflect differences bstween Pune and Bangalore as such.

The data both from Pune and Bangalore show a very great degree of variation. The standard deviations are close to half or sometimes more than half of the mean. The wide variation in egg developmental times is primarily because there is a significant degree of egg cannibalism which remains undetected. Eggs are eaten and replaced by new ones and several consecutive replacements may occur before an egg successfully hatches into a larva. The variation in larval developmental times almost certainly reflects differences in food supply. A larva can complete development and pupate in as little as 7 days in Bangalore under labolatory conditions when the adults feeding the larva are provided with an ad libitum food supply (Gadagkar, unpublished observations). The variations in pupal develop- 
Table 3. Brood developmental times*

\begin{tabular}{|c|c|c|c|c|c|c|c|c|c|}
\hline & \multicolumn{3}{|c|}{$\begin{array}{c}\text { From weekly } \\
\text { abservations in Pune }\end{array}$} & \multicolumn{3}{|c|}{$\begin{array}{c}\text { From daily } \\
\text { observations in Pune }\end{array}$} & \multicolumn{3}{|c|}{$\begin{array}{c}\text { From weekly } \\
\text { observation in Bangalore }\end{array}$} \\
\hline & Mean & $\begin{array}{l}\text { Standard } \\
\text { deviation }\end{array}$ & $\begin{array}{l}\text { Sample } \\
\text { size }\end{array}$ & Mean & $\begin{array}{l}\text { Standard } \\
\text { deviation }\end{array}$ & $\begin{array}{l}\text { Sample } \\
\text { size }\end{array}$ & Mean & $\begin{array}{l}\text { Standard } \\
\text { deviation }\end{array}$ & $\begin{array}{l}\text { Sample } \\
\text { size }\end{array}$ \\
\hline Egg & 18 & 13 & 1221 & 12 & 8 & 64 & 27 & 15 & 43 \\
\hline Larva & 15 & 10 & 1052 & 10 & 5 & 37 & 22 & 7 & 28 \\
\hline Pupa & 16 & 8 & 1071 & 14 & 6 & 45 & 29 & 11 & 16 \\
\hline
\end{tabular}

* All means and standard deviations are in days. 
mental times are the hardest to understand. The hypothesis that a strong correlation between larval and pupal developmental times is the cause of this variation is not borne out because we find that the correlation coefficients between larval and pupal developmental times are not significantly different from zero at $5 \%$ level. This is true even in the large sample size from weekly observations in Pune.

\subsection{Duration of residence of adults on the nest}

In all nests in which the newly emerging adults were marked it was observed that the males always disappeared within two to four days of emergence. While some females disappeared very soon after emergence, others stayed on at the parent nest for long periods of time. On two nests all the emerging adults (a total of 75 females and 3 males) were marked. The 3 males disappeared from the nest within 2,3 and 4 days respectively of emergence. Of the 75 females we have information on the duration of residence on the nest for 60 females that disappeared before the end of our study. The frequency distribution of residence times for these 60 females is shown in figure 2. This corresponds to a (mean \pm SD) residence time of $27 \pm 23$ days and a range from 1-160 days. When a wasp disappears from one nest it may either have died (mortality) on initiated or joined another nest (emigration). In our records these two components cannot be distinguished directly. The (mean $\pm \mathrm{SD}$ ) age-specific day to day probability of remaining at the same nest (inset, figure 3) has a value of $0.95 \pm 0.04$ which is nearly constant with age. This seems to suggest that mortality as opposed to emigra tion forms a very large component of our estimates. The reasoning behind this is that mortality seems to occur during the foraging trips because the wasps simply do not return to the nest at the end of the day. Perhaps they are lost or preyed upon. It is reasonable to assume that the probability of these events would be

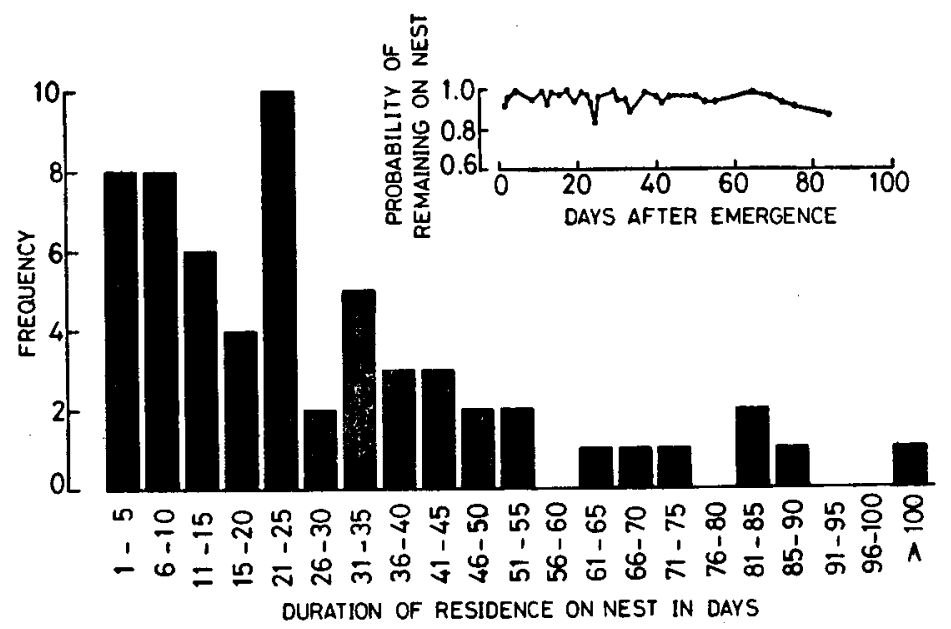

Figure 2. Frequency distribution of residence times on a given nest of 60 female wasps of $R$. marginata. The age-specific day-to-day probability of remaining at the same nest (inset) of $0.95 \pm 0.04$ is nearly constant with age. Note that most of the paints lie between 0.90 and $1 \cdot 0$, 
independent of the age of the animal but that the probability of emigration to found or join another nest would show some age dependence.

\subsection{Reproductive differentiation}

Our dissections from the harvested colonies indicate that although there is no morphological differentiation amongst the females, there is a marked differentiation amongst them in terms of development of ovaries. In all the nests, a majority of the females possessed rudimentary, completely undeveloped ovaries, while only 1 to 6 females possessed moderately or well developed ovaries. In most cases, the females with well-developed ovaries tended to be heavier in weight than the other females (Gadgil and Mahabal 1974). In addition there is a dominance hierarchy amongst the females at a nest with the dominant females doing less foraging (Gadagkar 1980). There is extensive food sharing at the nests of $R$. marginata, and since frequoncy of dominance behaviour and snatching food are significantly correlated (Gadagkar and Joshi 1983a) it is quite plausible that the dominant individuals get a disproportionately greater share of the food, while expending less energy on foraging. They may thus be able to grow heavier and develop their ovaries, while the less dominant individuals, the workers, suffer from 'nutritional castration'.

The number of females with developed ovaries does not bear any clear relation to the total number of females on the colony; while it shows evidence of an increase with the number of cells in the comb (table 4). Thirty out of 32 nests with less than 100 cells had a single egg-layer, while 14 out of 17 larger nests had 2 or more. The number of cells in a comb is a good indicator of the age of the colony, while the number of females in a colony keeps constantly fluctuating because of periodic large scile emergence and emigrations. We may therefore conclude that the number of egg-layers in a colony increases with the age of the colony. Initially, at the founding, a single female dominates and monopolises

Table 4. Nests with different numbers of egg layers

\begin{tabular}{|c|c|c|c|c|c|c|c|}
\hline \multirow{2}{*}{\multicolumn{2}{|c|}{$\begin{array}{l}\text { Number of } \\
\text { cells in nest }\end{array}$}} & \multicolumn{6}{|c|}{$\begin{array}{c}\text { Frequency of nests with different numbers of females with well } \\
\text { developed ovaries (egg-layers) }\end{array}$} \\
\hline & & $\begin{array}{c}1 \\
\text { egg-layer }\end{array}$ & $\begin{array}{l}2 \\
\text { egg-layers }\end{array}$ & $\begin{array}{l}3 \\
\text { egg-layers }\end{array}$ & $\begin{array}{c}4 \\
\text { egg-layers } \\
\end{array}$ & $\begin{array}{c}5 \\
\text { egg-layers }\end{array}$ & $\begin{array}{l}6 \\
\text { egg-layers }\end{array}$ \\
\hline $1-100$ & 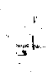 & 30 & 2 & 1 & 0 & 0 & 0 \\
\hline $101-200$ & & 2 & 1 & 1 & 1 & 1 & 2 \\
\hline $201-300$ & & 1 & 0 & 0 & 1 & 0 & 0 \\
\hline $301-400$ & & 2 & 1 & 0 & 1 & 0 & 0 \\
\hline $401-500$ & & 0 & 1 & 1 & 0 & 0 & 1 \\
\hline
\end{tabular}


all egg-laying ; as the colony develops, this monopoly is broken and other females again the heavier, more dominant ones, also begin to lay eggs.

\subsection{Population fluctuations}

Nests of $R$. marginata that have long life spans are characterised by continuous fluctuations in the number of adults. Figures 3 and 4 represent the population changes at two nests which grew to a considerable size and lasted for two years or more. In both cases the number of adults on the nests increased initially and following one or more mass emigrations, remained fluctuating for several months at less than 20 adults. In the case of the first nest (figure 3) there were four clear cut instances of mass emigrations. These involved 30 or more adults leaving the nest perhaps to initiate other nests nearby. In the case of the second nest (figure 4), there was a single major exodus, apparently in direct response to predation on the nest by Vespa tropica. This large wasp feeds on eggs, larvae and pupae of $R$. marginata. The particular nest depicted in figure 4 was under continual observation, and it is known that the mass exodus followed the first ever visit of the predator to the nest. The predator continued to regularly visit this nest thereafter, and apparently kept the population in check for a year or so. Beyond this period, the nest failed to grow further, although the visits of the predator apparently ceased.

We have rather complete information on population fluctuations at one site in Bangalore where we observed all the nests present at that site for a period of 104 weeks. In all, 35 nosts were observed at this study site. The number of nests and the total population of adults and pupae present in all the nests at different times at this site are shown in figure 5. The total population of adults varied between 70 and 400, the population of pupae between 0 and 340 and the total number of nests present at any given time varied between 8 and 16. The largest number of adults were present during January to April in both years. However, the number of pupae and that of the nests seemed to fluctuate rather widely.

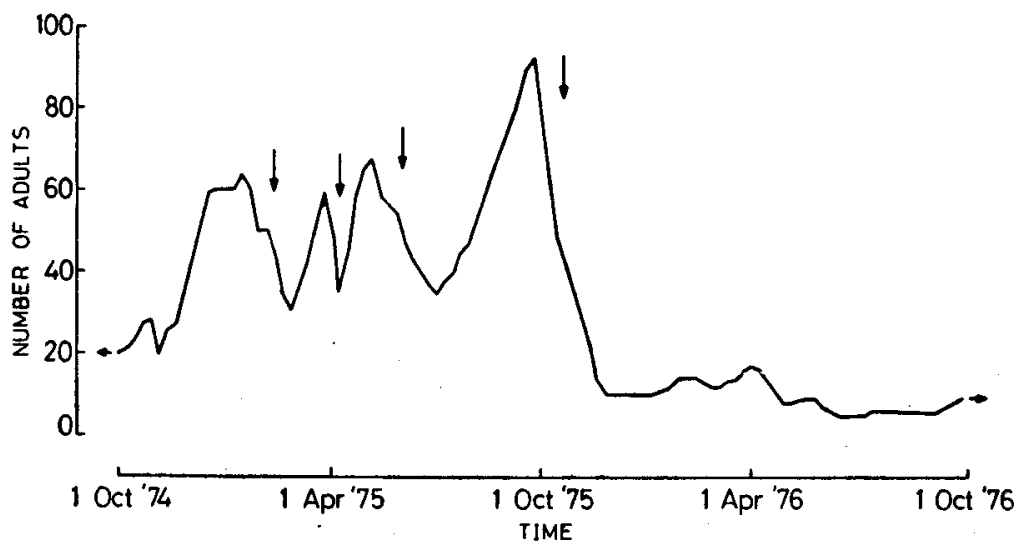

Figure 3. Number of adults at a Ropalidia marginata nest in Bangalore, The arrows indicate mass exoduses. 


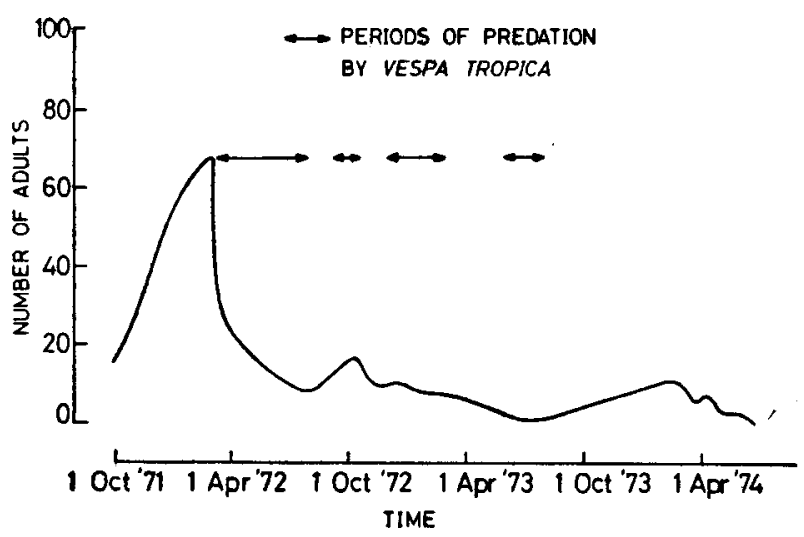

Figure 4. Number of adults at an $R$. marginata nest in Pune. There was a single exadus following the first instance of predation on the nest by Vespa tropica. Arrows indicate periods of regular predation by this wasp.

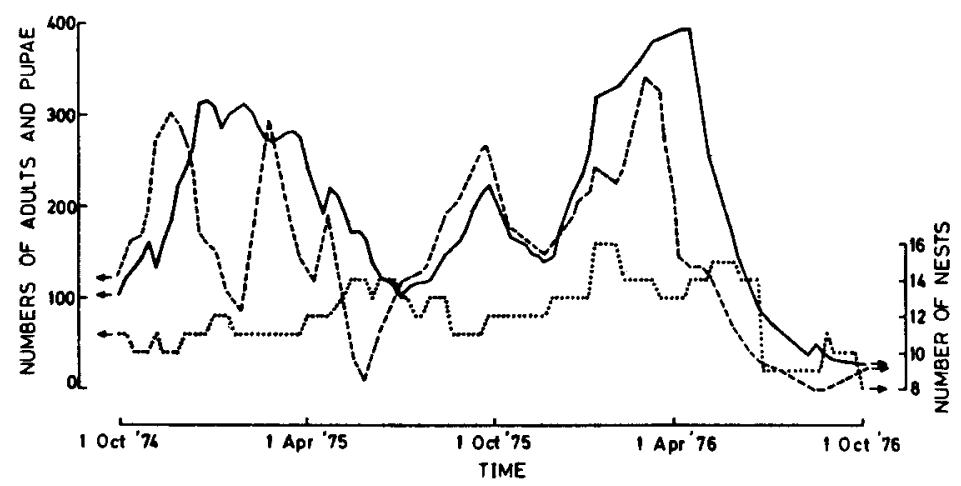

Figure 5. The tatal number of adilts (left ordinate and solid line) and pupae (left ordinate, broken line) and the tatal number of nests (right ordinate and dotted line) present at different times at a single study site in Bangalore over the period of 104 weoks.

The long lived nests represented in figures 3 and 4 are only a small proportion of the total nests. Most of the nests in fact have a shorter life span. The total life span of 18 nests is known because both the initiation and abandoning of these nests occurred during the period of study. The frequency distribution of total life span of these nests (figure 6A) shows that most nests $(70 \%)$ have a live span of 10 weeks or less. There was only one nest among these that survived for longer than 30 weeks. However, estimates of the total life spans obtained from any finite period of study is likely to be biased in favour of short lived nests. The distribution of minimum life spans, i.e., where either initiation or abandoning alone were observed (figure 6B) reveals that 10 out of 16 additional nests survived for longer than 30 weeks. Moreover, for one nest neither initiation nor abandoning was observed; in other words, it survived for longer than 104 weeks (the dura- 

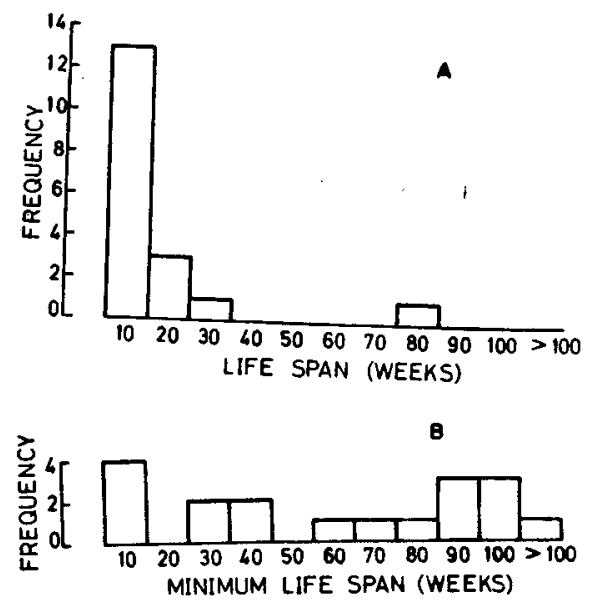

Figure 6. Frequency distribution of total life spans (A) and minimum life spans (B) of $\boldsymbol{R}$. marginata nests. Total life span is defined as the time interval between initiation and abandoning of a nest and is therefore known only for those nests for which both initiation and abandoning occurred during the period of study. Minimum life span is given only for those nests for which either the initiation or abandoning alone is known.

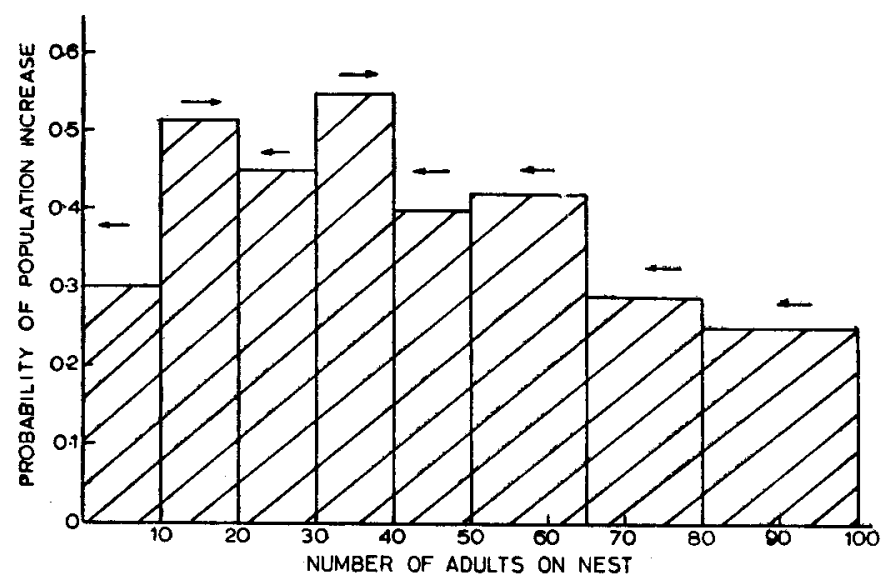

Figure 7. Probability of increase in adult numbers as a function of number of adults already present. The arrows indicate the expected change on the mean in the number of adults in colonies of various sizes.

tion of observation). Thus, although most nests are short lived, some do survive for very long periods of time.

Figure 7 presents further analysis of the population fluctuations. Here we present the probability of increase in the number of adults at a nest as a function of the number of adults already present. These probabilities have been computed by pooling together our data for the 8 nests monitored for over 2 years. As can 


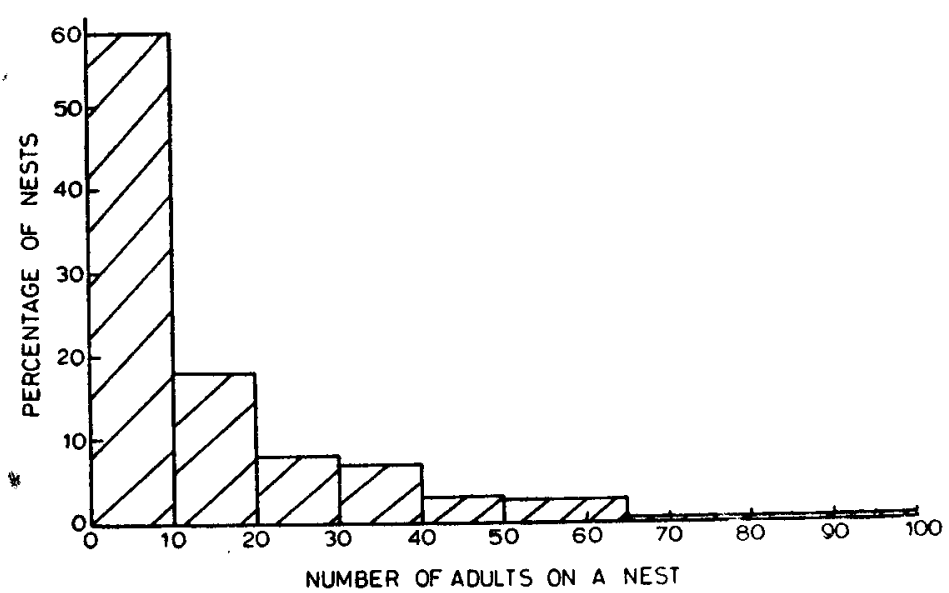

Figure 8. Frequency distribution of the total population of $R$. marginata nests in terms of the number of adults present on the nest.

be seen, the smallest nests have the lowest probability (only 0.3 ) of further increase in number. They are thus nests most susceptible to extinction. The only sizes at which the nests have near even or better than even chance of increase are between 10 to 40 . Thus, a nest which has increased to this level may further increase rapidly till it crosses 40 adults. Beyond this, the nests tend to have a high probability of decrease (due to mass exoduses). The resultant size frequency distribution of nests is presented in figure 8 . $^{\circ}$ The vast majority of the nests have less than 10 adults, most go extinct without getting beyond this stage.

\section{Discussion}

According to the theory of kin selection (Hamilton 1964a, b ; 1972 ; West. Eberhard 1975) the rationale for the development of sociality in ants, bees and wasps lies in their haplodiploid system of sex determination. Because of this, a female wasp is genetically more closely related to her sister than she is to her daughter, and it is therefore more 'advantageous' for a female wasp to help her mother raise daughters which would be her sisters, than to attempt to raise daughters by herself. It is believed that this is why females are selectively favoured to stay on with their mother and help her with the colony labour. At the same time, sons are more closely related to females than brothers are; hence the workers would have a tendency to lay male eggs, and the males themselves would not share in the colony labour (Hamilton 1964a, b; Wilson 1971; West-Eberhard 1975; Trivers and Hare 1976).

Wasp nests with multiple foundresses and multiple egg layers do not fall neatly in this scheme, particularly if the egg-laying females themselves were not close relatives. We however know that in the case of Polistes the foundresses do in fact tend to be sisters (West-Eberhard 1969 ; Ross and Gamboa 1981). This system of multiple foundresses can evolve if the nests are highly susceptible to failure in the early stages of growth. Then, if the coming together of several 
females increases the probability of success of a nest by a factor of 1.5 or mone, sisters may band together, and relinquish reproduction to the most dominant female as the female brood they are raising will be related to them as nieces with coefficient of relatedness $=0 \cdot 375$. If a single female remains reproductive, the workers of the later brood will be raising their sisters with coefficient of relatedness $=0.75$.

If, however, more than one of the founding sisters starts to lay, the workers will now be raising a brood related at least in part to them as first cousins coefficient of relatedness $=0 \cdot 19$. At this point the workers may find it more advantageous to leave the nest and attempt to initiate one on their own. This tendency will increase with an increase in the number of egg-layers in the nest.

As discussed earlier, the small nests of $R$. marginata are in fact highly susceptible to failure, hence the banding together of several foundresses is expected. We have no evidence that these are sisters, though this is plausible as new nests are very often founded close to old ones and the foundresses are likely to be sisters who leave together in an exodus from a nest.

We have also shown that there is a tendency for mass exoduses from nests with over 40 adults. This may be related to these being older nests with multiple egglayers in which the average degree of relationship between the workers and the brood would tend to be low, making it less advantageous for the workers to stay on at nest. Difficulties of sustaining a larger number of adults on the food resources of the home range could be ruled out as a major factor since the new nests are often founded next to the parental nest and must therefore utilize much the same food resources.

In conclusion it appears that ecological pressures render small nests highly susceptible to failure and therefore necessitate the banding together of several females. As the nest grows in size, a single female can no longer dominate it to the level of exclusively monopolizing all egg-laying. With the emergence of multiple egg-layers the workers are at less of an advantage in remaining on the nest and hence begin to leave in significant numbers producing large population fluctuations. An interaction of ecological and social pressures thus determine the course of growth of a nest.

\section{Acknowledgements}

We are grateful to $\mathrm{O} W$ Richards for his kind help in identifying the $R$. marginata and $V$. tropica material.

\section{References}

Alexander R D 1974 The evolution of social behaviour; Ann. Rev. Ecol. Syst. 5 325-383

Belvadi V V and Govindan R 1981 Nesting habits and behaviour of Ropalidia (Icariola) marginata (Hymenoptera : Vespidae) in South India ; Colemania 1 95-101

Carl J 1934 Ropalidia montana sp. et son nid. Un type nouveau d' architecture vespienne; Rev. Suisse. Zool. 41 677-691

Darchen R 1976 Ropalidia cincta, guepe sociale de la savane de Lamto (Cote-D'Ivoire); Ann. Soc. Entomol. Fr. (NS) 12 579-601

Evans $\mathrm{H}$ E and West-Eberhard M J 1970 The wasps Ann Arbor, The Univ. of Michigan press: pp. 265 
Gadagkar R 1980 Dominance hierarchy and division of labour in the social wasp, Ropalidia marginata (Lep.) (Hymenoptera : Vespidae) ; Curr. Sci. 49 772-775

Gadagkar R and Joshi N V 1982a Behaviour of the Indian Sacial Wasp Ropalidia cyathiformis (Fab.) on a nest of separate combs (Hymenoptera : Vespidae); J. Zool. 198 27-37

Gadagkar R and Joshi N V 1982b A Comparative study of social structure in colonies of Ropalidia, in The Biology of the Social Insects, (eds) M D Breed, C D Michener and H E Evans, Prac. IX congress of the International Union for the study of social Insects, Boulder, Colorado USA pp. 187-191

Gadagkar R and Joshi N V 1982c When a wasp colony splits In The Biology of the Social Insects, (eds) $\mathrm{M} D$ Breed, $\mathrm{C} D$ Michener and $\mathrm{H} \mathrm{E}$ Evans Proc. IX congress of the International union for the Study of Social Insects, Boulder Colorado USA pp. 217

Gadagkar R and Joshi N V 1983a Quantitative ethology of social wasps : Time-activity budgets and caste differentiation in Ropalidia marginata (Lep.)(Hymenoptera: Vespide); Animal Behaviour 31 26-31

Gadagkar $\mathbf{R}$ and Joshi $\mathbf{N}$ V $1983 \mathrm{~b}$ Sociai organization in the Indian wasp Ropalidia cyathiformis (Fab.) (Hymenoptera : Vespidae) ; Z. Tierpsychol. (in Press)

Gadgil M and Mahabal A S 1974 Caste differentiation in the paper wasp Ropalidia marginata (Lep.); Curr. Sci. 43482

Hamilton W D 1964a The genetical evolution of social behaviour I ; J. Theor. Biol. 7 1-16

Hamilton W D 1964b The genetical evolution of social behaviour II;J. Theor. Biol. 7 17-52

Hamilton W D 1972 Altruism and related phenomena mainly in the sacial insects; Ann. Rev. Ecol. Syst. 3 193-232

Jeanne R L 1972 Social biology of the Nea-tropical wasp Mischocyttarus drewseni; Bull. Mus. Comp. Zool. Harv. Univ. 144 63-150

Jeanne R L 1980 Evolution of social behaviour in the Vespidae ; Ann. Rev. Entomol. 25 371-396

Lin N and Michener C D 1972 Evolution of sociality in insects; Q. Rev. Biol. 47 131-159

Litte M 1977 Behavioural ecology of the social wasp, Mischocyttarus mexicanus; Beh. Ecol. Sociobiol. 2 229-246

Litte M 1979 Mischocyttarus flavitarsis in Arizona : social and nesting biology of a polistine wasp ; $Z$. Tierpsychol. $50 \quad 282-312$

Litte M 1981 Social biology of the Polistine wasp Mischocyttarus labiatus : survival in a Calombian rain forest; Smiths. Contr. Zool. No. 327

Michener C D 1969 Comparative social behaviour of bees; Ann. Rev. Entomol. 14 299-342

Michener C D 1974 The social behaviour of the bees; Massachussetts : Harvard University Press xii +404 pp.

Richards O W and Richards M J 1951 Observations on the social wasps of South America (Hymenoptera : Vespidae) ; Trans. Roy. Entomol. Soc. Lond. 102 1-170

Ross N M and Gamboa G J 1981 Nestmate discrimination in social wasps (Polisters metricus, Hymenoptera : Vespidae); Beh. Ecol. Sociobiol. 9 163-165

Roubaud E 1916 Recherches biologiques sur les guepes sociales et cosales d'Afrique. La guese de la vie social et l' evolution de 1 'instinct maternal chez les vespides; Ann. Sci. Nat. Zool. 1 1-160

Saussure H de 1853-59 Monographie de quepes sociales, ou de la tribu des Vespiens, onvrage faisant suite a la monogrophie des guiepes solitaires $V$. Masson Paris

Starr C K 1979 Origin and evolution of insect sociality; A review of madern theory; In Social Insects, (ed) H R Hermann (New York : Academic Press) Vol. I pp. 35-79

Trivers R L and Hare H 1976 Haplodiploidy and the evolution of the social insects ; Science 191 249-263

Vecht J Van der 1962 The Indo-Australian species of the genus Ropalidia (Icaria) (Second part); Zool. Verhand. Leiden 57 1-72

West-Eberhard M J 1969 Social biology of polistine wasps; Misc. Publ. Mus. Zool. Univ. Mich. 140 1-101

West-Eberhard M J 1975 The evolution of social behaviour by kin selection: Q. Rev. Biol 50 1-33

Wilson E O 1971 The insect societies; Massachussetts : Harvard University Press x + 548 pp. Wilson E O 1975 Sociobiology; Massachussetts: Harvard University Press ix +697 pp. 